\title{
MICROBIOLOGICAL PROFILE IN PATIENTS WITH CONGENITAL NASO LACRIMAL DUCT OBSTRUCTION
}

\section{Dr. N. V. N Prasanna Bharathi*}

\section{Dr. P. Ramdas}

\section{Dr. M. Padma}

Dr. Sowmya Andole
M.S Ophthalmology, Ex Junior Resident Sarojini Devi Eye Hospital, Hyderabad. *Corresponding Author

Assistant professor of Ophthalmology, Sarojini Devi Eye hospital, Huymayun nagar, Hyderabad .500028 T.S.

Associate professor of Ophthalmology, Sarojini Devi Eye hospital, Huymayun nagar, Hyderabad. 500028 T.S.

M.S Ophthalmology, Ex Senior Resident, Sarojini Devi Eye hospital, Hyderabad.

ABSTRACT AIM: To study and evaluate the different organisms that are responsible for congenital nasolacrimal duct obstruction .To initiate appropriate antimicrobials based on the sensitivity patterns of the isolated organisms. Methods: It is a prospective study conducted in Sarojini Devi Eye hospital during September 2016 to February 2018. 112 samples from 100 cases were collected from clinically diagnosed congenital nasolacrimal duct obstruction with epiphora below 1 year without any ocular and systemic diseases. Swabs taken were analysed for causative microorganisms of congenital nasolacrimal duct obstruction. Results: In our study out of 112 samples[88 unilateral cases + 12 bilateral cases ]82 cases [73.21\%] were culture positive, of which80 [71.42\%]were bacterial,2 cases [1.78\%]were mixed [ bacterial +fungal].Gram positive bacteria were predominant, staphylococcus epidermidis 56[68.29\%] followed by Staphylococcus aureus 13[15.85\%].Among gram negative bacteria Escherichia coli 1 [1.21\%], klebsiella 1[1.21\%]. 2 cases were mixed [bacteria + fungal]. Infection is more commonly seen in right eye. Rate of infection was higher in females 62[55.35].Higher incidence of infection was seen in the age group of less than 7 months. Both gram positive and gram negative were most susceptible to tobramycin.Conclusion: Among all the congenital nasolacrimal duct obstructions $90 \%$ of the cases would resolve spontaneously with medical therapy and Criggler massage. $10 \%$ of the cases require probing and silicon tube intubation. The knowledge of identification, awareness and bacteriology of congenital nasolacrimal duct obstruction by the paediatricians, physicians and the parents would contribute to the choice of effective antimicrobials and reduce keratitis medicamentosa, induced astigmatism due to excessive eye rubbing and apprehension among the parents.

\section{KEYWORDS : Congenital nasolacrimal duct, Epiphora, Microorganisms, Probing.}

INTRODUCTION:

Congenital nasolacrimal duct obstruction is a common condition that results in epiphora (excessive tearing) early in life. Congenital naso lacrimal duct obstruction occurs in $5 \%$ of the normal newborn infants. Most (approximately 90\%) clear spontaneously during the first year of life. (1)(2)(3) The lacrimal excretory system is responsible for draining excess tears and is composed of the canaliculi, the lacrimal sac, and the nasolacrimal duct. The most common cause is the failure of a membrane at the end of the tear duct (valve of Hasner) to open normally at or near the time of birth. Other causes of blocked tear ducts in children include, absent puncta (upper and/or lower eyelids) narrow tear duct system and infection.

Children with Down syndrome, Craniosynostosis, Goldenhar syndrome, clefting syndromes, hemi facial microsomia, or any midline facial anomaly are at an increased risk for congenital nasolacrimal duct obstruction .Congenital naso lacrimal duct obstruction may affect one or both eyes. Tearing does not always suggest nasolacrimal duct obstruction, as this symptom may occur in other conditions, such as exposure to irritants, eyelid malposition, abnormal eye lashes, or congenital glaucoma, which may be identified on careful examination. Infants present with excessive tearing or mucoid discharge from the eyes because the natural drainage system is blocked. Obstruction of the nasolacrimal duct results in stasis with the accumulation of tears, desquamated cells, and mucoid secretions. This creates a fertile environment for secondary bacterial infections. Morbidity is related primarily to the lacrimal sac abscess and spread of the infection. The primary morbidity is associated with chronic lacrimation, matting, and conjunctival inflammation and infection. As many as $30 \%$ of new born infants are believed to have closure of nasolacrimal duct at birth. If not treated promptly and aggressively, newborn infants can experience orbital cellulitis (because the orbital septum is formed poorly in infants), brain abscess, meningitis, sepsis, and death.

The purpose of this study is to identify the bacterial aetiology in congenital nasolacrimal duct obstruction and to determine the in vitro antibacterial susceptibility and resistance of bacterial pathogens to commonly used antibacterial agents. $90 \%$ of the CNLD resolves spontaneously with medical therapy and Criggler massage within 1 st year. Only $10 \%$ of them requires probing and silicon tube intubation.

\section{MATERIALS AND METHODS:}

This is a prospective study done at a tertiary eye care government medical college hospital from 2016 to 2018.The study includes 100 infants with congenital nasolacrimal duct obstruction attended to Paediatric Ophthalmology outpatient department with the complaint of watering of eyes.

\section{INCLUSION CRITERIA :}

All the infants with congenital nasolacrimal duct obstruction without any eye disease are included.

\section{EXCLUSION CRITERIA:}

1.Infants with CNLDO with other ocular and systemic manifestations are excluded.

2.Infants with CNLDO without parents consent are excluded.

\section{METHODS:}

A complete history and examination of eyes and ocular adnexa was done. Specimen collected after cleaning with normal saline swab, pressure was applied on medial epicanthetic fold, the regurgitant pus or serosanguinous fluid 
was collected by sterile swab. Two sterile cotton swabs moistened with physiological saline were used for collection of discharge from the lacrimal punctum, ensuring that the lid margin or conjunctiva was not touched. Specimen processing One swab was spread on two labeled slides to prepare smears. The direct smears so made and stained by Gram stain and $\mathrm{KOH}$ method for fungal elements. The second swab was used for inoculation into culture media like Brain Heart Infusion broth (BHI), Blood agar (BA), Mac Conkey (MA), Chocolate agar (CA) Sabouraud dextrose agar (SDA). The inoculated media were incubated at $37^{\circ} \mathrm{C}$ for 24 to $48 \mathrm{hrs}$. A positive culture was defined as a growth of the same organisms on more than two solid phase media or confluent growth on one solid medium and smear results consistent with cultures.

A standardized protocol was followed for each ocular specimen for the evaluation of significant microbiological features. In vitro susceptibility testing was performed by KirbyBauer disc diffusion method and interpreted using Clinical and Laboratory Standards Institute's serum standards.(4) The antibacterial agents (Himedia Laboratories Pvt. Ltd., Mumbai, India) used were amikacin (30 $\mu \mathrm{g} /$ disk), tobramycin ( $10 \mu \mathrm{g} /$ disk), gentamicin ( $10 \mu \mathrm{g} /$ disk $)$, ceftazidime (30 $\mu \mathrm{g} /$ disk), ciprofloxacin (5 $\mu \mathrm{g} / \mathrm{disk})$, norfloxacin ( $10 \mu \mathrm{g} / \mathrm{disk})$, ofloxacin (5 $\mu \mathrm{g} /$ disk), gatifloxacin (5 $\mu \mathrm{g} /$ disk), moxifloxacin $(5 \mu \mathrm{g} /$ disk $)$, chloramphenicol ( $30 \mu \mathrm{g} /$ disk) were consistently tested for their efficacy . All the isolates were subjected to cefoxitin disc diffusion test using a cefoxitin ( $30 \mu \mathrm{g} /$ disk). A 0.5Mc Farland standard suspension of the isolate was made and lawn culture was done on Mueller Hinton agar plate. Plates were incubated at $35^{\circ} \mathrm{C}$ for $18 \mathrm{hr}$ and zone diameters were measured. An inhibition zone diameter of $\leq 21 \mathrm{~mm}$ was reported as resistant and $\geq 22 \mathrm{~mm}$ was considered as sensitive.

\section{Identification of fungal ocular pathogens:}

The fungal elements were observed in $10 \% \mathrm{KOH}$ mount and Gram stain. The fungi were identified based upon the colony characters, such as texture, color, growth rate on obverse side of Sabouraud's dextrose agar slants and presence of pigment on the reverse side of colony and whether the pigment was localized or diffuse. A lactophenol cotton blue mount was done for the microscopic features like mycelium, conidium relationship between hyphae and fruiting bodies.

RESULTS: Our prospective study of 100 patients with 112 samples of clinically diagnosed congenital nasolacrimal duct obstruction

Table 1: Distribution of culture positive cases

\begin{tabular}{|c|c|c|}
\hline Total cases & No of patients & Percentage \\
\hline No.cases studied & 112 & $100 \%$ \\
\hline No.of positive & 82 & $73.21 \%$ \\
\hline No.of negative & 30 & $37.33 \%$ \\
\hline
\end{tabular}

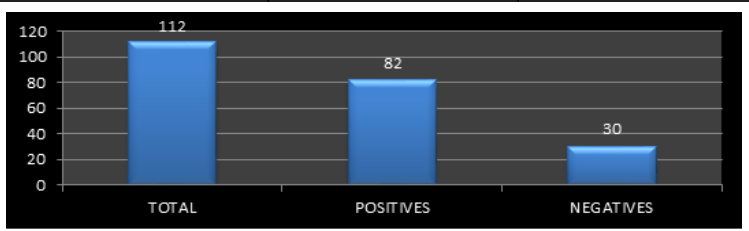

GRAPH 1:DISTRIBUTION OF CULTURE POSITIVE CASES

In our study no of samples collected were 112 from 100 patients of CNLD. Out of 112 samples $73.21 \%$ were culture positive. $27.33 \%$ were culture negative

GENDER DISTRIBUTION: In our study out of $112,73.21 \%$ samples were culture positive. Out of 112 cases $55.35 \%$ were seen in females and $44.64 \%$ were seen in males.
TABLE 2. GENDER DISTRIBUTION

\begin{tabular}{|c|c|c|}
\hline Gender & No.of samples & Percentage \\
\hline Female & 62 & $55.35 \%$ \\
\hline Male & 50 & $44.64 \%$ \\
\hline
\end{tabular}

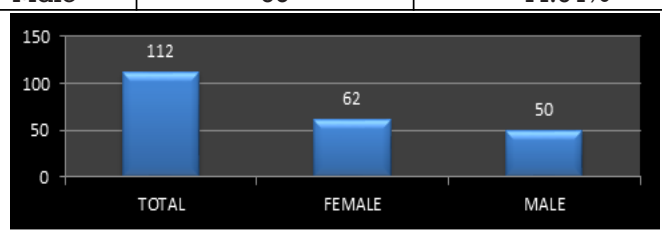

GRAPH 2:GRAPH DEPICTING GENDER DISTRIBUTION

Laterality:

In our study the involvement of eye was mainly unilateral $(75.60 \%)$ either the right eye or left eye and there were also some bilateral cases(24.39\%) .Among unilateral right eye $(42.68 \%)$ was predominant.

Table: 3 LATERALITY

\begin{tabular}{|c|c|c|c|}
\hline Infected eye & Total samples & Growth & Percentage \\
\hline Right eye & 48 & 35 & 42.68 \\
\hline Left eye & 40 & 27 & 32.92 \\
\hline Both eyes & 24 & 20 & 24.39 \\
\hline Total & 112 & 82 & 73.21 \\
\hline
\end{tabular}

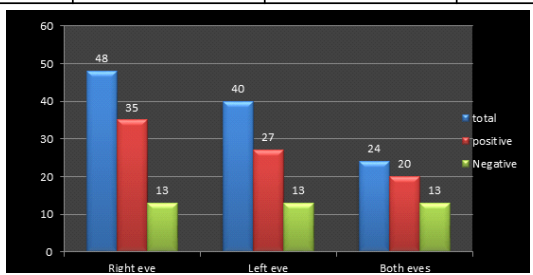

GRAPH 3:Laterality distribution of positive cases

Age distribution: The age of the patients in the study ranged from lmonth to 12 months, majority of cases were seen in 3-4, 56 months of age in female gender constituting $35 \%, 22 \%$.

Table 4:Age wise distribution

\begin{tabular}{|c|c|c|c|c|c|}
\hline $\begin{array}{c}\text { Age group } \\
\text { in months }\end{array}$ & Female & Male & $\begin{array}{c}\text { No of cases } \\
\text { studied }\end{array}$ & $\begin{array}{c}\text { No of } \\
\text { positive } \\
\text { cases }\end{array}$ & Percentage \\
\hline $1-2$ & 7 & 5 & 12 & 8 & 10 \\
\hline $3-4$ & 17 & 14 & 31 & 29 & 35 \\
\hline $5-6$ & 13 & 10 & 23 & 18 & 22 \\
\hline $7-8$ & 10 & 5 & 15 & 13 & 16 \\
\hline $9-10$ & 7 & 3 & 10 & 8 & 10 \\
\hline $11-12$ & 6 & 3 & 9 & 6 & 7 \\
\hline
\end{tabular}

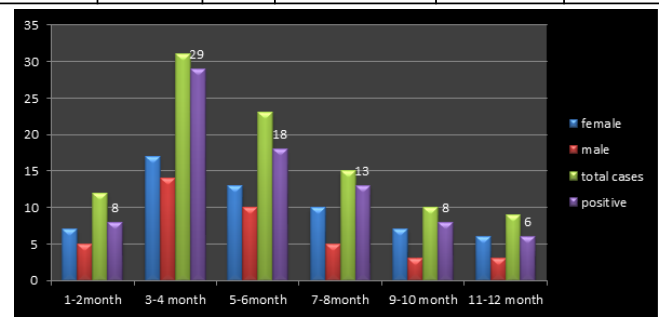

GRAPH 4:

GRAPH DEPICTING AGE AND GENDER DISTRIBUTION IN THE PRESENT STUDY MICROBIOLOGICAL PROFILE: In this study among 82 culture positive, 80 [71.42\%] cases were purely bacterial isolates and 2[1.78\%] cases were mixed [bacterial +fungal] isolates. Among 80 [71.42\%] bacterial isolates, 78 [97.50\%] were gram positive, $02[2.50 \%]$ were gram negative.

Among 78 gram positive cases,staphylococcus epidermidis $56(68 \%)$,staphylococcus aureus $13(16 \%)$, streptococcus pneumoniae $6(10 \%)$, enterococcus feacalis $3(3.5 \%)$ and 2 were gram negative E-coli l $1.21 \%$, kleibsiella l( $1.21 \%)$. 
TABLE 5:MICROBIOLOGICAL PROFILE IN OUR STUDY

\begin{tabular}{|c|c|c|}
\hline ORGANISIM ISOLATED & $\begin{array}{c}\text { NO OF POSITIVE } \\
\text { SAMPLES }\end{array}$ & PERCENTAGE \\
\hline $\begin{array}{c}\text { Staphylococcus } \\
\text { epidermidis }\end{array}$ & 56 & $68 \%$ \\
\hline Staphylococcus aureus & 13 & $16 \%$ \\
\hline $\begin{array}{c}\text { Streptococcus } \\
\text { pneumoniae }\end{array}$ & 6 & $10 \%$ \\
\hline Enterococcus feacalis & 3 & $4 \%$ \\
\hline E coli & 1 & $1 \%$ \\
\hline Klebsiella & 1 & $1 \%$ \\
\hline $\begin{array}{c}\text { Streptococcus +fusarium } \\
\text { fungus }\end{array}$ & 2 & \\
\hline
\end{tabular}

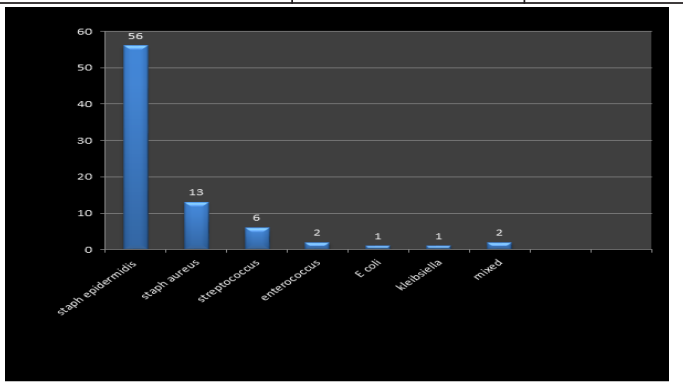

GRAPH 5:DISTRIBUTION OF DIFFERENT ISOLATES

Drug susceptibility of different isolates: In this study most of the isolates are susceptible to tobramycin, moxifloxacin and chloramphenicol.

Table 6: Drug susceptibility of different isolates

\begin{tabular}{|c|c|c|c|c|c|c|}
\hline ANTIBIOTIC & $\begin{array}{c}\text { Staphylococ } \\
\text { epidermidis }\end{array}$ & $\begin{array}{c}\text { Staphyl } \\
\text { ococcus } \\
\text { eureus }\end{array}$ & $\begin{array}{c}\text { Strept } \\
\text { ococc } \\
\text { us }\end{array}$ & $\begin{array}{c}\text { Enter } \\
\text { ococc } \\
\text { us }\end{array}$ & $\begin{array}{c}\text { richia } \\
\text { coli }\end{array}$ & $\begin{array}{c}\text { Kleib } \\
\text { siella }\end{array}$ \\
\hline ciprofloxacin & 42.8 & 54.5 & 98 & 25 & - & - \\
\hline Ofloxacin & 57.1 & 45.4 & 99 & 25 & - & - \\
\hline Gatifloxacin & 85.7 & 81.8 & 100 & 50 & - & - \\
\hline Moxifloxacin & 100 & 81.8 & 100 & 50 & & - \\
\hline $\begin{array}{c}\text { Chloramphe } \\
\text { nicol }\end{array}$ & 85.7 & 90.9 & 100 & 75 & 100 & 100 \\
\hline $\begin{array}{c}\text { Ceftazidime } \\
\text { Gentamicin }\end{array}$ & 71.4 & 27.2 & 100 & 50 & 100 & - \\
\hline Tobramycin & 100 & 91.8 & 100 & 80 & 100 & - \\
\hline
\end{tabular}

\section{DISCUSSION :}

The most common infection of the lacrimal apparatus is dacryocystitis. The lacrimal excretory system is prone to infection and inflammation in infants with CNLDO. This mucus membrane-lined tract is contagious with two surfaces (conjunctival and nasal mucosal) that are normally colonized with bacteria. The functional purpose of the lacrimal excretory system is to drain tears from the eye into the nasal cavity. Obstruction of the nasolacrimal duct from whatever source results in stasis with the accumulation of tears, desquamated cells, and mucoid secretions above the level of obstruction25. This creates a fertile environment for secondary bacterial infection (5). The present study includes 100 patients with 112 samples of clinically diagnosed congenital nasolacrimal duct obstruction which were studied for microbial involvement of which $82(73 \%)$ were culture positive cases and $30(27 \%)$ were no bacterial growth.(table 1).This is in accordance with the study of Kuchar et al .In their study $72.64 \%$ cases were positive out of 50 samples where as Usha et al (17) study analysed $83 \%$ positive cultures from 238 samples .This is due to large sample study.

In our study female predominance was seen. This is in accordance with Chaudhary et al., (2005), where study was predominated to female subjects $65.4 \%$.This is also in accordance with the study of Prakash et al..,2012.(23) reported that CNLD is more predominant in females due to narrow bony canal in females.In our study , the involvement of the eye was mainly unilateral [88\%],bilateral cases were [12\%].This is in accordance with the study of Prakash et al..,2012(23) reported that incidence of CNLD is high unilaterally either right eye or left eye.

In the present study there was a relatively high incidence of the disease on the right side[54\%], as compared with the left side [45.45\%].

Age wise distribution of culture positive cases in the present study were predominantly seen in 3-4,5-6 months of age constituting 35\%,22\%(chart 5 ).

This is in accordance with the study of Ffooks et al..,1962(21) and Mahwish Jawaid et al ..,2017.(25) Among 82 culture positive,80[71.42\%] cases were purely bacterial isolates and $2[1.78 \%]$ cases were mixed[bacterial + fungal] isolates. In this study among $80[71.42 \%]$ bacterial isolates $78[97.50 \%$ ] were gram positive and $2[2.50 \%$ ] were gram negative.

Usha et al in their study in 2006(17) also obtained 57\% gram positive bacteria and $43 \%$ gram negative bacteria , $1(0.5 \%)$ fungal isolate from $83 \%$ culture positive cases.This is also in accordance with the study of Prakash et al..,2012.(23) .Bareja $\mathrm{U}$ et al 1990 study also reveals that streptococcus pneumonia were $28.9 \%$ and staphylococcuc epidermidis $11.4 \%$ out of $57.9 \%$ cases.According to Usha et al.,2006 study (57\%) isolates were gram positive bacteria, the most frequent isolate being Streptococcus pneumonia .Gram negative bacteria accounted for $(43 \%)$ of the isolates, the most frequent isolate being Haemophilus influenza. There was one fungal isolate $(0.5 \%)$ of Candida tropicalis. In the present study, most of the gram positive cocci were susceptible to Tobramycin, chloramphenicol and were equally susceptible to Gentamycin, moxifloxacin and gatifloxacin.This is in accordance with BHAVANA RAINA et al studied 37 eyes of 30 congenital dacryocystitis patients (7 bilateral), out of which $60 \%$ of patients were male and $40 \%$ female. Gram positive cocci constituted the major bacterial isolate (56.7\%) with Streptococcus pneumonia $(27.9 \%)$ predominating. Most effective antibiotics against the commonest organism Streptococcus pneumoniae were Tobramycin and Gentamycin showing $100 \%$ effectivity. Staphylococcus albus $17.4 \%$ was the most common normal conjunctival commensal isolated. .In the present study gram negative organisims were sensitive to chloramphenicol and tobramycin.This is in correlation with the studies of Kebede et al., (2010), who reported the antibiotics to which the majority of the isolates sensitive to were chloramphenicol (82.4\%), gentamycin (79.1\%). (24) Among Gram negative organisms most of them are susceptible to chloramphenicol, gatifloxacin and tobramycin. Bharathi et al., (2010), reported all Gram positive cocci were most frequent isolated from ocular infections and were most sensitive to moxifloxacin and Gram negative were most sensitive to amikacin and gatifloxacin. Majority of the isolated organisms were least sensitive to ciprofloxacin and ofloxacin.

\section{CONCLUSION:}

1. In the present study the commonest organism isolated was staphylococcus epidermidis[68.29\%].

2. It was well established as a normal commensal of the conjunctiva along with diptheroids.(16)

3. A number of reports have proved its pathogenicity in postoperative ocular infections, blepharoconjunctivitis and corneal ulcer.(16)We should not ignore it as a mere commensal.(16)

4. Our study shows that all congenital nasolacrimal duct obstruction cases should be routinely investigated for staphylococcus epidermidis and its sensitivity patterns. 
The knowledge of identification, awareness and bacteriology of CNLD by the paediatricians, physicians and the parents would contribute to the choice of effective antimicrobials. It would reduce the keratitis medicamentosa, anisometropia and apprehension among the parents. In this study we did not follow up all the cases whether they needed probing in future.

\section{REFERRENCES}

1. Paul TO. Medical management of congenital nasolacrimal duct obstruction. J Pediatr Ophthalmol and Strabismus. 1985; 22:68-70.

2. Nelson, LB, Calhoun, JH, Menduke, H. Medical management of congenital nasolacrimal duct obstruction. Ophthalmology. 1985:92:1187-1190.

3. Petersen, RA, Robb, RM. The natural history of congenital obstruction of the nasolacrimal duct. J Pediatr Ophthalmol and Strabismus. 1978; 15:246-250. Robb RM. Success rates of nasolacrimal duct probing at time intervals after 1 year of age. Ophthalmology 1998;105:1307-9.

4. Ciftci F, Akman A, Sonmez M, et al. Systematic, combinedtreatment approach to nasolacrimal duct obstruction in different age groups. Eur J Ophthalmol 2000;10:324-9.

5. Casady DR, Meyer DR, Simon JW, et al. Stepwise treatment paradigm for congenital nasolacrimal duct obstruction. Ophthal Plast Reconstr Surg 2006;22:243-7

6. Baker JD. Treatment of congenital nasolacrimal system obstruction. J Pediatr Ophthalmol Strabismus 1985:22:34-6.

7. Katowitz JA, Welsh MG. Timing of initial probing and irrigation in congenitalnasolacrimal duct obstruction.Ophthalmology 1987;94:698-705.

8. Stager D, Baker JD, Frey T, et al. Office probing of congenital nasolacrimal duct obstruction.Ophthalmic Surg 1992;23:482-4.

9. Engel JM, Hichie-Schmidt C, Khammar A, Ostfeld BM, Vyas A, Ticho BH Monocanalicular silastic intubation for the initial correction of congenital nasolacrimal duct obstruction. JAAPOS. 2007; 11:183-186.

10 Becker BB, Berry FD, Koller H. Balloon catheter dilatation for treatment of congenital nasolacrimal duct obstruction. Am J Ophthalmol. 1996; 121:304.

11 A randomized trial comparing the cost-effectiveness of 2 approaches for treating unilateral nasolacrimal duct obstruction. Arch Ophthalmol. 2012; 130:1525-1533.

12 Clark RA. Dilation probing as primary treatment for congenital nasolacrimal duct obstruction. JAAPOS. 2002; 6:364-367.

13 Pediatric Eye Disease Investigator Group, Repka MX, Chandler DL, Beck RW, Crouch ER 3rd, Donahue S, Holmes JM, Lee K, Melia M, Quinn GE, Sala NA Schloff S, Silbert DI, Wallace DK. Primary treatment of nasolacrimal duct obstruction with probing in children younger than 4 years. Ophthalmology. 2008; 115:577-584.

14 Soliman M. Lueder GT. Initial management of congenital canalicular atresia. JAAPOS. 2015; 19:220-222

15 Lueder GT. The association of neonatal dacryocystoceles and infantile dacryocystitis with nasolacrimal duct cysts (an American Ophthalmological Society thesis). Trans Am Ophthalmol Soc. 2012; 110:74-93.

16. Gerkowicz M. Koziol-Montewka M. Pietra -Trazpiel M., Kosior-Jarecka E. Szczepanik A., Latalska M. Identification of bacterial flora of conjunctival sac in congenital nasolacrimal duct obstruction in children.Klin Oczna. 2005; 107(1-3):83-85.

17 Usha K, Smitha S, Shah N, Lalitha P, Kelkar R, Spectrum and susceptibilities of microbial isolates in cases of congenital naso lacrimal duct obstruction. JAAPOS 2006; 10 (5); 469-472

18 Bareja U, Glose S. Clinico bacteriological correlates of congenital dacryocystitis. Indian JOpthalmol. 1990; 38(2): 66-69

19 Mac Ewen C.J., Phillips M.G., Young J.D., Value of Bacterial Culturing in the course of congenital naso lacrimal duct obstruction. J Pediatric Ophthalmol Strabismus 1994: 31(4) 246-250.

20 Ghose S. Mahajan VM: Microbiology of congenital dacryocystitis- Its clinical significance. J. Ocul. Ther. Surg. 4:54-57, 1985

21 Ffooks Dacryocystitis in Infancy, Br J Ophthalmol 1962 46: 422-434 11.

22 Iliff NT. Infections of the lacrimal drainage system. In: Peopse JS, Holland GN, Wilhelmus KR (eds). Ocular Infection and Immunity. Mosby: St Louis, MO, 1996, 1346-55.

23 Prakash R., Girish Babu R.J., Nagaraj E.R., Prashanth H.V., Jayashree S. Shah Journal of Clinical and Diagnostic Research. 2012 May (Suppl-2), Vol6(4): 6526559 .

24. Kebede A, Adamu Y, Bejiga A. Bacteriological study of dacryocystitis among patients attending in Menelik II Hospital, Addis Ababa, Ethiopia. Ethiop Med J 2010 48(1): 29-33.

25. Mahwish Jawaid, Aruna Sunder and Pratibha. 2017. Microbial Flora of Dacryocystitis and its Antibiogram. Int.J.Curr.Microbiol.App.Sci. 6(12): 10131020

26 PiotrowskiJT,DiehlNN,Mohney Arch opthalmol 2010;128:1166.

27 Peterson RA, Robb, RM. The natural history of the congenital obstruction of the naso lacrimal duct. J pediatric ophthalmol and strabismus 1991:28:302-303.

28 Cassidy, TC, Dacryocystitis infancy AMJ Ophthalmol 1948; 31:773-780

29 Kuchar A., Lukas J., Steinkogler FJ. Bacteriology and antibiotic therapy in congenital nasolacrimal duct obstruction. Acta Ophthalmol Scand. 2000;78(6):694-698

30 Value of microbiology study in congenital nasolacrimal duct obstruction. Yasser H. Al-Faky,a,* Tahir Naeem,b Nora Al-Sobaie,a Reem Al-Huthail,a Hessa Al-Odan, a Essam A. Osman, a andAhmad MousaaSaudi J Ophthalmol. 2012 Apr; 26(2): 223-228.

31 ww.jkscience.org/archive/volumel24...Clinico bacteriological significance in congenital dacryocystitis Bhavna Raina, Sudir bagohtra.

32 Parson's Diseases of the eye 21st edition, Section vi ,Diseases of the Adnexa 29,461-469.

33. American academy of Ophthalomology,Orbit,Eyelids, and Lacrmal system,2014-2015,BCSC,Section 7,Part lll,pg no 243-277.

34 Chaudhary M., Bhattarai A., Adhikari S.K., Bhatta D.R. (2010). Bacteriology and antimicrobial susceptibility of adult chronic dacryocystitis. Nepal Ophthalmol; 2(4): 105-113.

35 Bharathi M.J., Ramakrishnan R., Maneksha V.,Shivakumar C., Nithya V.,Mittal S (2008).Comparitive bacteriology of acute and chronic dacryocystitis. Eye;(22) 7:253-60

36 Scott E.H., Mike J.B., Kevin C., Anirvan B. (2007).Dacryocystitis presenting as post-septal cellulitis: a case report. Journal of Medical Case Reports; 1:77.

37 Shah C P et al Bacteriology of dacryocystitis Nepal J Ophthalmol 2011;3(6):134-139

38 Daniel B., Alexander R., Ehud I.A. (2005).Changing bacterial isolates and antibiotic sensitivities of purulent dacryocystitis. Orbit; 24(2): 95-8.

39 Gaynor B.D., Chidambaram J.D., Cevallos V.,Miao Y., Miller K., Jha H.C. (2005). Topical ocularantibiotics induce bacterial resistance at extraocularsites. BrJ Ophthalmol; 89(90):1097-1099. 